\title{
Introducing Discomforts
}

\author{
SOPHIE SUNDERLAND \\ UNIVERSITY OF WESTERN AUSTRALIA \\ HOLLY RANDELL-MOON \\ MACQUARIE UNIVERSITY
}

'Secular Discomforts: Religion and Cultural Studies' invites debate about the enactment of scholarship at the discursive juncture of religion, secularism and cultural studies. For the purposes of this special issue we have co-located questions of religion and secularism as objects of intellectual analysis and aligned them paradigmatically with a posture of anxiety. This alignment represents a keenness to unsettle the normative understanding that the secular is associated with neutrality, objectivity and rationality in opposition to the category of religion. We acknowledge that this arousal of interests in religion, secularism, and cultural studies might be seen to pique anxieties. As John Frow acknowledged in his influential essay, 'Is Elvis a God?':

Religion is an embarrassment to us. It's an embarrassment to me, and above all because we Western intellectuals are so deeply committed to the secularization thesis which makes of religion an archaic remnant which ought by now to have withered away. ${ }^{1}$

Frow was writing in 1998, at a time when the secularisation thesis-the sociological contention that religious affiliation and activity in the West had continuously 
declined since the 1950s-was under renewed contention (and has since been revisited and debunked by a number of scholars). ${ }^{2}$ Of course, religion has not withered away as a category of enquiry, and yet a certain kind of withering might be detected in the orientation toward religion Frow so candidly depicts. In the face of the religious, narratives of an assuredly 'secular' cultural studies might be seen to suffer a withering blow. This raises important questions about investments in particular narratives of secularism that underpin cultural studies scholarship. We are pleased to introduce a range of essays that grapple with questions of how cultural studies, secularism and religion are enacted at intersections that upset and discomfort binary logic. Hence, this special issue offers new conceptual paradigms for doing scholarship at the limits of normative (secular and religious) comforts.

The articles that comprise this section are related through their capacity to unsettle and occupy a position of discomfort, rather than appeasement, in their engagements with cultural studies, secularism and the religious. Critical to this capacity is resistance to the idea that 'religion' and 'cultural studies' are irreconcilable opposites, or that 'secularism' might form the neutral ground upon which to stage debate. Rather, in offering this collection we are keen to unsettle the idea that the secular underwrites analyses of the religious and, further, that the secular marks the terrain from which cultural studies is enacted. In this way the secular appears across this issue as a set of iterations at times strange rather than familiar, intolerant rather than inclusive, specific rather than universal, problematic rather than resolved, and hegemonic rather than neutral. Given the historical and cultural ideological loading of the terms we use (secularism, religion and cultural studies), our title may not appear to indicate the degree of nuance and critical daring each essay brings to the debate. However, by positioning 'discomfort' as a central posture with critical perspicacity, 'Secular Discomforts' presents the opportunity for discussion and debate that endures the excitations, upsets and uneasinesses which mark spaces where discourses of religion and secularism meet.

To engender discomfort is to deprive one of comfort, easiness and, in older usages, courage. The Oxford English Dictionary describes discomfort as a verb meaning to distress, grieve or sadden. ${ }^{3}$ Hence, discomfort can be read as an indication that a loss of easiness has taken place. Yet it can be read more productively as a term that indicates a positive unmaking of the conditions 
associated with the relative comfort of familiarity and ease. Enquiry into the politics of discomfort includes paying critical attention to what counts as the experience or sense of comfort which must be, by definition, a priori. For example, what might it mean to critique the idea that secularism works to comfortably separate religion from the discourses that shape everyday life in secular liberal democracies? To unsettle or cause discomfort around secularism might include critical approaches to the notion that secularism belongs as easily to the paradigms of violence, ruptures and divergences as it does tolerance, neutrality and peace. Rather than interpreting discomfort as a stricken moment-a critical caesura in conversation, methodology and praxis - for the purposes of this collection we utilise discomfort as a practice of scholarly vitality. As David Eng and David Kazanjian, as well as Sara Ahmed, have theorised in the last decade, this collection offers engagements with a 'positive' grammar of loss. Here, we emphasise the productivity and sociality of lost comfort, ease and familiarity in critical engagements with the religious and secular. ${ }^{4}$

-DIS-COMFORTING POLITICS

This collection has its origins in intermittent conversation. Having discovered one another's work at the graduate conference Not Another Hijab Row: New Conversations on Gender, Race, Religion, and the Making of Communities hosted by the Trans/Forming Cultures research centre at University of Technology Sydney in 2006, we shared our common interest in the limits and paradoxes of secular policy and discourse in Australia. Over the years our conversations have contained some wonder about the lack of paradigmatic discussions of secularism in the Australian context and within cultural studies as a discipline to date-especially to a greater extent in cultural studies' seminal literature. This is a critique that has been made within cultural studies and hence is not new. ${ }^{5}$ However, the cultural context in which we embarked on our research projects demanded theoretical and ethicopolitical paradigms for understanding and unsettling incursions of the 'religious' into 'secular' politics and public life.

The year 2006 was the final stretch of what are now colloquially known as the 'Howard years' of conservative government in Australia. The unsettling affects and effects associated with former prime minister John Howard's coalition government (1996-2007) include the closer proximity between church and state enacted in 
debates in relation to references to Almighty God in the Preamble to the Constitution, assertive commitments to Christianity in parliamentary processes, a discursive privileging of Judeo-Christianity in political rhetoric, and a suite of policies and programs including the National Chaplains in Schools program, the Job Network scheme, the National Pregnancy Support Helpline and family relationship centres that used federal government funding to support religious, specifically Christian, intervention in state institutions. ${ }^{6}$ These local manifestations of a religious form of governance were refracted through the larger geopolitical conflict known as the 'war on terror'. It was under these conditions that our conversations became concerned with the ways cultural studies scholarship might intervene upon the political and social space established by a secularism that appeared unruly to the principle of separation of church from state.

The Australian context is both different from and yet not dissimilar to a range of critical questions raised globally within this time period. Ann Pellegrini and Janet Jakobsen's special issue of Social Text titled 'World Secularisms at the Millenium' constitutes a crucial intervention to the debate we stake out here. The issue presciently called the conceits of global secularisms into discussion at the turn of the twenty-first century, just as the necessity of a critical approach to secularism became increasingly urgent. Indeed, commenting on this political context in his 2007 keynote address for the Cultural Studies Now conference held at the University of East London, Stuart Hall argued that one of the challenges currently facing cultural studies was to explain why an Islamic fundamentalist movement has so far constituted the only significant opposition to neoliberal capitalism.

You don't understand and I don't understand either how the long history of secular enlightenment ends up with the major opponent of the capitalist global system in a religious formation. We really don't know anything about hoe [sic] this came about. This is a cultural question, if there is a cultural question-what is the place of religion today and why does it move around in this way in relation to social struggles of different kinds?7

As stated earlier in his speech, cultural studies is focused on 'the role of culture, not as a dependant, but as a constitutive dimension of the social formation, articulated without reduction to other key processes in different ways in each conjuncture'. ${ }^{8}$ Religion and secularism are certainly contested through the domain of 'culture' in 
the present, in terms of a 'clash of cultures' or 'civilisations' between a simplified binary of the West and Islam ${ }^{9}$ and the focus on 'culture' as an arena where governments attempt to shore up social cohesion against the threat of 'terrorism' through multicultural or inter-faith initiatives. ${ }^{10}$ In this vein, Ien Ang has noted that cultural studies might usefully intervene in the moral panics generated out of religious 'difference' as a political and social problem, particularly with regards to Lebanese youth. 'It would be the distinctive intellectual contribution of cultural studies research ... to highlight the fact that the very demonization of Lebanese boys as potential criminals may be in part of the whole problem.'11 Culture then is the discursive site through which different types of religious values and expression are deemed acceptable or unacceptable to a Western secular polity.

'Secular Discomforts' represents a broadening of our conversations to include diverse voices that engage with questions of secularism and religion from the terrain of culture. It is not surprising that our desire to canvas these concerns grew out of the 'Howard years'; a decade known for the discursive preoccupation with feeling comfortable about dominant accounts of Australian culture and history. This is perhaps best encapsulated by Howard's well-known statement that the posture of the Australian people when encountering difference, religious or otherwise, ought to be 'relaxed and comfortable'. Feelings of relaxation and comfort brought on by a sense of cultural familiarity were central to Howard's discourse. What counts as the cause, condition and experience of comfort in this use of language appears to be the familiar. Discomforting familiarity would entail seizing upon that which is assumed, or ordinary, in ethical and critical practice. This is a rich and vital space from which to approach questions of secularism, religion and cultural studies. Given that secularism is commonly posited as a neutral ground for debate, and tertiary institutions are placed firmly within its purview, the conceits, prejudices and affective experiences of living (with) secularism may not be readily legible. As a number of scholars have pointed out, secularism produces our understandings of religion as well as acceptable forms of religious expression and action. ${ }^{12}$ Hence, to upset the normativity of secularisms within cultural studies paradigms offers an excitation to radically reconsider the secularism/religion, reason/dogma, modern/premodern binary oppositions. 
John Frow's suspicion of the secularisation thesis was timely given the scholarly debates that questioned the validity of this thesis in the 1990s. Indeed, in his 1967 study The Sacred Canopy renowned sociologist Peter Berger felt able to describe Western culture as largely, and successfully, secularised. He argued that the dwindling of 'religion' in the public sphere and intellectual institutions in both Western and non-Western societies was a fact of progress. ${ }^{13}$ However, he revised his position in 1999 by echoing Frow's assertion to concede 'a whole body of literature by historians and social scientists loosely labelled "secularization theory" is essentially mistaken'.14 This revision was based on empirical evidence showing rising interest in religion in both the West and non-Western, African and South American nations. ${ }^{15}$ Other scholars too have subjected this explanation of a decline in religious power to sustained criticism. The main thrust of these critiques is that the secularisation thesis is too broad and homogenising. David Nash points out that 'historical knowledge about statements of religious belief, of legal jurisdiction, of power and of cultural changes that have a religious dimension increasingly do not fit into conventional secularization models'. ${ }^{16}$ Some religions, such as Christianity, can exercise a cultural power in 'Western' nations even as liberal secularism requires a separation of church and state. As Saba Mahmood notes, secularism is both 'an analytical standpoint and a political field of intervention'.17 Any engagement with religion therefore requires a concomitant engagement with the cultural and institutional operation of secularism.

As the articles that comprise this special issue demonstrate, secularism cannot be extricated from its cultural context and relation to power. Anthropologist of religion and secularism Talal Asad argues that the secular is not simply a 'negative' term always already linked to the presence or absence of 'religion,' but instead, and more profoundly, constitutes a complex, contingent conceptual and juridical apparatus that makes corporeal, subjective and political space. ${ }^{18}$ The implications of this understanding of the secular are wide-ranging, but for the purposes of this collection are elegantly demonstrated by Ann Pellegrini's rousing exploration of democratic engagement with difference in the making of an 'agonistic public square'-with discomfort as its necessity. Grappling sensitively with the political implications of secularisms in the making of lived, political spaces, Pellegrini deftly 
weaves the question, indeed structure, of feeling into debates about how secularism legitimates feeling subjects, and subjections to feeling.

In this vein it is instructive to return to Frow's description of feelings of embarrassment that accompany incursions of religiosity in Western intellectual traditions and practices. At first blush it may seem that Frow indicates 'religion' is an artefact met by embarrassment and, hence, is productive of discomfort. Yet his curiosity about this feeling invites further curiosity about the temper of debate. If we consider Asad's suggestion that secularism-with which academe is commonly associated-makes social and subjective space, and is contextually specific, the embarrassment engendered by encountering religion in 'safe' secular spaces can be thought of as a provocation to critique the conditions in which this feeling is made. How might forms of secularism invite and produce postures of humiliation, dismissal and uneasiness in relation to religious difference?

An appropriate locus upon which to place this consideration is the cultural studies classroom. We have discussed experiences teaching cultural studies coursework where, relatively frequently, a student has prefaced their response to a topic with a phrase like, 'I'm Christian, so ...' This qualification would appear to appease uncertainty about the premises of the response, and perhaps the anxiety inherent in learning about questions of subjectivity. It is not uncommon and worthy of further consideration. Yet Holly relayed an arresting question from a student in an introductory cultural studies course. The unit introduced students to discourse analysis and processes of signification, which some students found challenging. During a one-on-one consultation with a student, they discussed the Derridian notion that 'there is nothing outside the text' in some detail. ${ }^{19}$ The student appeared to grasp the basics of the methodological apparatus; texts refer to other texts, there's no 'original' or 'authentic' meaning, or at least we don't know because we only have textual and discursive meanings to guide us. Nodding, the student then asked somewhat surprisingly, 'if all texts refer to other texts, then what is God? Is God discursive?' It was difficult to formulate a response to this question, other than to reiterate that religion wasn't a topic covered in the unit.

The urgency of this special issue resides in the residues of uncertainty, excitation and provocation this question elicited. As Ruth Barcan and Jay Johnston acknowledge in their call to expand the reach of cultural studies to alternative 
therapies and religion, such a question is underpinned by the idea that discourses of religiosity might exhaust paradigms and methodologies focused on Foucauldian conceptions of power, knowledge and identity. ${ }^{20}$ The question of whether god is discursive reveals a misunderstanding in its request for a declarative answer, but this is the least interesting aspect of it. Rather, here the positionality of religion in the (secular) cultural studies classroom looms as it is called into question. To absorb the religious within discursive reality might risk the disavowal of difference, or the severing of that which exceeds the paradigm. To avoid the question might enact another kind of disavowal, where something of embarrassment, or discomfort, looms. And of course the question of religion is more complex than the religious/secular dichotomy suggests, with many inconsistencies and contingencies that frustrate, upset and vitalise.

Although secularism and religion have been renewed as a paradigm of analysis within cultural studies, as well as other disciplines in recent years, the import of this issue is that it seeks to approach these questions from the space where secularism's hold on neutrality and ordinariness is contested. Broadbrush concepts such as secularism, which are articulated differently in different sociopolitical spaces and moments, are also notoriously difficult to pin down. As per Stuart Hall and Ien Ang, the urgencies associated with minorities in transnational political and cultural formations, renewed attention on border security and flows of religious ideology through media outlets, immigration policies, identity politics and uses of public space have required close critical attention since John Frow wrote in 1998. In bringing together a range of approaches to the way in which secularism sets in motion, engages, critiques, promotes or perhaps calms discomfort within cultural studies discourse, the articles that follow have in common the vitalising aspects of discomfort that make and mark social and intellectual space for new engagements with the embodied, social phenomena we call 'religion'.

\section{-SECULAR DISCOMFORTS}

While secularism is often invoked as a means of remedying religious conflict, the first article in this issue, by Ann Pellegrini, explores the ways secular liberal tolerance is underwritten by what she (along with Janet Jakobsen) refers to as 'Christo-normativity'. Pellegrini contests the neutrality often assigned to secular 
juridical and public spaces by showing how a Christo-normativity permeates discussions of national belonging in North America such that expressions of Christianity are rendered comfortable and compatible with liberal secular American norms. By contrast, media and political rhetoric about Cordoba House, the proposed Islamic community centre in downtown Manhattan, and moral panics about Shariah law construct the public expression of non-Christian faiths, and Islam in particular, as discomforting and even a threat to secular cultural norms. Creating a public space where religious difference does not have to be sublimated to a secular neutrality (that benefits some and excludes others) means that for Pellegrini, 'agonistic democratic pluralism is an unfinished project'.

This closely argued, rousing contribution sets the issue in motion as Pellegrini's critique discomforts normative ideas of secularism and artfully frames concerns that are differentially taken up in the papers that follow. Picking up from Pellegrini's mapping of the asymmetries involved in juridico-political manifestations of liberal secularism, Goldie Osuri focuses on debates around the secular and post-secular in an Indian context. Working through a range of political and theoretical responses to Indian secularism, Osuri teases out the difficulties in utilising the critical and ethical resources of a secularism underwritten by Eurocentric theological norms. Rethinking secularism as a means of political intervention and engagement is fraught with challenges in a context where Hindu nationalist politics have had devastating effects on religious minorities and historically, separate state formations have been the solution to religious and ethnic conflict. In pointing to the limitations of liberal Western accounts of secularism and the particularities of Indian secularism, Osuri's article reveals the necessity and urgency of thinking and acting secular in ways that do not reproduce 'other' religions as forms of 'difference' that need to eliminated or recuperated into a dominant secular-national order.

Moving away from the discomfort the secular state engenders for particular religious groups, the next two articles engage with the commodification of religion and spirituality under secular capitalism. Guy Redden looks at the economies of New Age spirituality that seem 'to valorise cultural others' by eschewing institutional authority and doctrinal inflexibility in favour of a 'spiritual marketplace' that requires 'proactive syncreticsim' for spiritual enlightenment. Such a marketplace marries endless transformation of the self and absorption of diverse spiritualities 
with continuous cycles of consumption. This process of spiritual and economic transformation raises questions about the distribution and control of spiritual knowledge when it becomes commodified, as with the controversies over ownership and licensing of the book and DVD, The Secret. Redden points out that these problems are particularly acute when Indigenous cultural beliefs are imported into a spiritual marketplace that is disconnected from sites of struggle and resistance to colonialism. In a similar vein, Chris Klassen turns her attention to the refraction of 'indigenous' spirituality in James Cameron's environmental fantasy film Avatar. Using Bron Taylor's notion of 'dark green religion'. Klassen contends that the film's digital construction of a religiously inflected form of nature works to displace an ostensible concern with the environment and Indigenous peoples onto a marvelling of the spectacle of 'nature' in the film. The film fails as a form of public pedagogy for Klassen by suggesting, as with New Age spirituality, that spiritual or political consciousness can be obtained through consumption alone.

These reconstructions of indigenous spirituality through secular conceptions of the market and the self make visible the colonising imperatives that underwrite notions of 'religion', 'culture' and 'knowledge.' Christina Petterson explores the intersections of secular governance and religious conversion in the context of the Danish colonisation of Greenland. Working with Michel Foucault's conceptualisation of pastoral power as embedded in secular forms of governmentality, she considers how Greenlanders were disciplined and transformed into 'good' Danish subjects according to a racialised, Lutheran familial structure. In doing this, she also points to some of the Roman Catholic assumptions and biases in Foucault's conceptualisation of disciplinary power, the body and governmentality. These limitations notwithstanding, the article is instructive in demonstrating how Foucault links religion to modern forms of power and how his work complicates a Western secular narrative of the development of political and governmental power. Edwin $\mathrm{Ng}$ also draws on Foucault's accounts of religion and the construction of the self to explore the imbrications between faith, knowledge and ethics in cultural studies' disciplinary paradigms. This exploration, predicated on 'a profession of faith', seeks to articulate his practice as a cultural studies scholar and Vispassana Buddhist with poststructuralist theories of subjectivity. Framing these personal and professional practices through a reading of Foucault, Ng asks whether cultural studies' 
commitment to diversity and alterity as an ethico-political project would benefit from a (re)consideration of the ways faith informs our scholarly work and lives.

The concluding essay by Nick Mansfield forms an incisive close to the collection as its exploration of sovereignty and violence returns to the questions indicated in Pellegrini's opening essay. A reading of the historical figure Gilles de Rais through Georges Bataille, Mansfield's essay considers the ways in which religion arrogates to itself the sovereign right to kill and perform violence and how this creates a human subjectivity that would seek security from/under this sovereign social and political arrangement. This is a sovereignty that seeks to both contain and enact violence as a means of future security; similar to the violence often justified in the name of democracy and other forms of transcendental logics. A deconstructive politics then reveals how religion is 'an instantiation of the nexus of violence, subjectification and truth-dealing that we call sovereignty'. What would religion look like and how might we come to know religion outside this deconstructive politics?

The writers who have written discomfort into their consideration of religion, secularism and cultural studies contribute to a critical paradigm that holds consideration for the ethical and political implications of intersections between subjectivity, feeling and social space. The essays that follow are invitations and provocations to wrest with the violences that are enacted when conversations cease to take place: the terrain upon which an unsettling, uneasy relation to what counts as cultural studies ought to insist.

Sophie Sunderland is an honorary research fellow in cultural studies at the University of Western Australia. She has published on the cultural politics of secularism, embodiment, and cultural grief in Australian and Canadian media cultures in the Review of Education, Pedagogy and Cultural Studies, and Australasian Canadian Studies. She was awarded a Travelling Fellowship by the Australian Academy of the Humanities in 2012 for new research on community memory related to the material sites and cultures of two former psychiatric institutions in Toronto, Canada and Perth, Australia. In a divergent area of interest, she has 
recently published on the neocolonial politics of 'friendly feeling' in Western coffee trade practices in $M / C$ Journal.

Holly Randell-Moon teaches cultural studies at Macquarie University, Sydney. She has published widely on race, religion and secularism in the journals Critical Race and Whiteness Studies, borderlands and Social Semiotics and in the collections Religion, Spirituality and the Social Sciences (2008) and Mediating Faiths (2010). Her publications on popular culture, gender, and sexuality have also appeared in the edited book collection Common Sense: Intelligence as Presented on Popular Television (2008) and the journals Feminist Media Studies and Topic: The Washington \& Jefferson College Review.

\footnotetext{
-NOTES

1 John Frow, 'Is Elvis A God? Cult, Culture, Questions of Method', International Journal of Cultural Studies, vol. 1, no. 2, 1998, p. 207.

2 Secularisation (as distinct from secularism) is a theory developed primarily in sociology to explain why religion became historically separated from institutional positions of power in Western democracies.

3 Oxford English Dictionary, 2nd edn, 1989, <http://www.oed.com/view/Entry/53821>.

4 David Eng, and David Kazanjian (eds), Loss: The Politics of Mourning, University of California Press, Berkeley, 2003; Sara Ahmed, The Promise of Happiness, Duke University Press, Durham, 2010.

5 See Frow.

6 See Marion Maddox, For God and Country: Religious Dynamics in Australian Federal Politics, Department of the Parliamentary Library, Canberra, 2001 and God Under Howard: The Rise of the Religious Right in Australian Politics, Allen \& Unwin, Sydney, 2005.

${ }^{7}$ Stuart Hall, 'Cultural Studies Now', Centre for Cultural Studies Research, University of East London, 2007, p. 22, <http://www.uel.ac.uk/ccsr/culturalstudiesnow.htm>.

8 Ibid., p. 15.

${ }^{9}$ See for example Samuel P. Huntington, The Clash of Civilizations and the Remaking of World Order, Simon \& Schuster, New York, 2003; Bernard Lewis, Islam and the West, Oxford University Press, New York, 1993.

10 Goldie Osuri, 'Transnational Bio/Necropolitics and its Avatars (Australia/India), Somatechnics, vol. 1, no. $1,2011$.
} 
11 Ien Ang, 'Who Needs Cultural Research?' in Cultural Studies and Practical Politics: Theory, Coalition Building, and Social Activism, ed. Pepi Leystina, Blackwell, New York, 2005, p. 481.

${ }^{12}$ See for example Talal Asad, Formations of the Secular: Christianity, Islam, Modernity, Stanford University Press, Stanford, 2003; Saba Mahmood, Politics of Piety: The Islamic Revival and the Feminist Subject, Princeton University Press, Princeton, 2004; Tomoko Masuzawa, The Invention of World Religions, University of Chicago Press, Chicago, 2005; Charles Taylor, A Secular Age, Belknap Press of Harvard University Press, Cambridge, Mass, 2007.

13 Peter Berger, The Sacred Canopy: Elements of a Sociological Theory of Religion, Doubleday, NY, 1967. 14 Peter Berger (ed.), The Desecularization of the World: Resurgent Religion and World Politics, Ethics and Public Policy Center, Washington DC and Wm B. Eerdmans, Grand Rapids, 1999, p. 18.

15 Selected key texts that engage the limits of the secularisation thesis include: Berger, The Desecularization of the World; Reginald Bibby, Restless Gods: The Renaissance of Religion in Canada, Stoddart, Toronto, 2002; Steve Bruce, God is Dead: Secularization in the West, Blackwell, Malden, 2002; Gary Bouma, Australian Soul: Religion and Spirituality in the Twenty-first Century, Cambridge University Press, Port Melbourne, 2006; Pippa Norris and Ronald Inglehart, Sacred and Secular: Religion and Politics Worldwide, Cambridge University Press, Cambridge, 2004. Further studies that situate 'resurgent' religion within global politics include: David Westerlund (ed.), Questioning the Secular State: The Worldwide Resurgence of Religion in Politics, Hurst \& Co, London, 1996; Jeff Haynes, Religion in Global Politics, Longman, London and New York, 1998; Jonathan Benthall, Returning to Religion: Why a Secular Age is Haunted by Faith, I.B. Tauris, London and New York, 2008.

${ }^{16}$ David Nash, 'Reconnecting Religion with Social and Cultural History: Secularization's Failure as a Master Narrative', Cultural and Social History, vol. 1, p. 304.

${ }^{17}$ Saba Mahmood, 'Secularism, Hermeneutics, and Empire: The Politics of Islamic Reformation', Public Culture, vol. 18, no. 2, 2006, p. 335.

18 Asad, Formations of the Secular; Talal Asad, 'Reflections on Laicité and the Public Sphere', Social Science Research Council Items and Ideas, vol. 5, no. 3, 2005.

${ }^{19}$ Jacques Derrida, Limited Inc, Northwestern University Press, Evanston, 1988, p. 136.

20 Ruth Barcan and Jay Johnston, 'The Haunting: Cultural Studies, Religion and Alternative Therapies', Iowa Journal of Cultural Studies, vol. 7, 2005. 